Gi respons på artikler gjennom artiklenes kommentarfelt på tidsskriftet.no.

Innleggene publiseres fortløpende på Tidsskriftets nettside og et utvalg

av innleggene publiseres også i papirutgaven i spalten «Brev til redaktøren».

Redaksjonen forbeholder seg retten til å foreta redaksjonelle endringer.

Forfattere av vitenskapelige artikler har tilsvarsrett, jf. Vancouver-gruppens regler.

\section{Re: Familieplanlegging, graviditet og amming ved multippel sklerose}

Vi takker Holmsen og medarbeidere for responsen i Tidsskriftet nr. 1/2017 på vår artikkel om familieplanlegging, graviditet og amming ved multippel sklerose (MS) (1), der de ganske riktig påpeker at det er holdepunkter for at konsentrasjonen av metylprednisolon i morsmelk ser ut til å synke raskt etter infusjon. Vi prøvde faktisk å få med denne informasjonen før manuskriptet gikk i trykken.

$1000 \mathrm{mg}$ metylprednisolon i tre til fem dager brukes som behandling av multippel sklerose-attakker. Dette er en høy dose av et potent legemiddel, som kan absorberes fra spedbarnets tarm. Det er derfor viktig å vurdere om kunnskapsgrunnlaget er tilstrekkelig til å konkludere entydig med at amming er trygt, og om ulempene ved ammepause oppveier den usikkerheten som følger av et svakt kunnskapsgrunnlag.

Det finnes to kasuistikker om at konsentrasjonen i melken sank raskt etter infusjon av $1000 \mathrm{mg}$ metylprednisolon (2, 3). Oss bekjent er det ingen data for tilsvarende peroral behandling, som brukes i økende grad. En enkeltstående kasuistikk rapporterte at de høyeste konsentrasjonene etter peroralt inntak av lav dose ble målt etter to og syv timer (4).

Disse kasuistikkene gjenspeiler neppe variasjonen blant ammende kvinner, og er et veldig svakt kunnskapsgrunnlag. Argumentet om at det ikke er registrert uheldige effekter hos diende barn må ses i lys av at dette ikke har vært systematisk undersøkt, og at vi ikke vet hvor mange spedbarn som har vært eksponert. Manglende evidens beviser ikke at uheldige effekter ikke finnes.

Undertegnede har gått i bresjen for å liberalisere bruken av immunmodulerende medikamenter for gravide og ammende kvinner med multippel sklerose. Vi er takknemlige for støtten og diskuterer gjerne mer liberal bruk av metylprednisolon ved amming. Etter vårt skjønn er imidlertid dette både dårligere underbygd og mindre viktig enn adekvat immunmodulerende behandling før, under og etter svangerskap. Dette står selvfølgelig ikke nødvendigvis i motsetning til hverandre. Vi opplever imidlertid dessverre at enkelte kvinner med multippel sklerose føler press om å amme, og at dette fører til at de forsaker adekvat immunmodulerende behandling og derved pådrar seg unødvendig og invalidiserende hjerneskade.

\section{Trygve Holmøy}

trygve.holmoy@medisin.uio.no

Øivind Torkildsen

Trygve Holmøy (f. 1960) er seksjonsoverlege ved Akershus universitetssykehus og professor ved Universitetet i Oslo.

Ingen oppgitte interessekonflikter.

Øivind Torkildsen (f. 1979) er overlege ved Nevrologisk avdeling, Haukeland universitetssykehus og professor ved Kristian Gerhard Jebsen senter for MS-forskning, Klinisk institutt 1, Universitetet i Bergen.

Ingen oppgitte interessekonflikter.

\section{Litteratur}

1. Holmøy T, Torkildsen $\emptyset$. Familieplanlegging, graviditet og amming ved multippel sklerose. Tidsskr Nor Legeforen 2016; 136: 1726-9.

2. Strijbos E, Coenradie S, Touw DJ et al. High-dose methylprednisolone for multiple sclerosis during lactation: Concentrations in breast milk. Mult Scler 2015; 21: 797-8

3. Cooper SD, Felkins K, Baker TE et al. Transfer of methylprednisolone into breast milk in a mother with multiple sclerosis. J Hum Lact 2015; 31: 237-9.
4. Coulam CB, Moyer TP, Jiang NS et al. Breast-feeding after renal transplantation. Transplant Proc 1982; 14: 605-9.

\section{Re: Behandling eller aktiv monitorering ved prostatakreft?}

Det er prisverdig at Tidsskriftet refererer viktige funn fra ledende internasjonale tidsskrifter. En forutsetning er selvsagt at sentrale funn er korrekt gjengitt og fortolket, men forutsetningen blir ikke alltid oppfylt, dessverre. I Tidsskriftet nr. 20/2016 omtaler Matilde Risopatron Berg (1) funn fra to artikler fra PPROTECT-studien som nylig ble publisert i New England Journal of Medicine. Artiklene beskriver funn om henholdsvis prostatakreftspesifikk tiårsoverlevelse og livskvalitet hos engelske menn med lokalisert prostatakreft som i perioden 1999-2009 ble randomisert til enten radikal prostatektomi, høydose strålebehandling eller aktiv monitorering.

Basert på artikkelen til Hamdy og medarbeidere (2) refererer Berg at tiårsmortalitet «som følge av prostatakreft» var lik i de tre behandlingsarmene. Et forhold er at det korrekte fagutrykket her er «prostatakreftspesifikk mortalitet» Det anføres korrekt at progredieringsraten var signifikant høyere hos pasienter i armen for aktiv monitorering sammenlignet med de opererte eller strålebehandlede mennene. PROTECT-studien viser således at prostatektomi eller strålebehandling reduserer risikoen for progrediering av ikke-metastatisk prostatakreft. I denne sammenhengen savner man informasjonen om at 433 av 545 pasienter med aktiv monitorering ikke trengte noen form for lokalbehandling i løpet av følgende ti år. Dette er et funn som burde ha vært nevnt. Dessverre nevner Berg heller ikke funnet om at den prostatakreftspesifikke mortalitet var mindre enn $1,5 \%$ i alle tre behandlingsgruppene. Denne lave prosenten representerer et viktig faktum for informasjonssamtalene som urologer og onkologer har med pasientene før behandlingen starter.

Artikkelen til Donovan og medarbeidere (3) bekrefter de velkjente behandlingsrelaterte forskjellene i bivirkningsprofilen. Dessverre er referentens avslutning med noe lavere livskvalitet etter strålebehandling feilaktig, siden artikkelen beskriver den samme livskvaliteten for alle tre behandlingsgrupper ti år etter behandlingsstart. God livskvalitet er et prioritert mål $\mathrm{i}$ behandlingen av prostatakreft, og derfor er det viktig at sentrale funn formidles korrekt til Tidsskriftets lesere.

I referentens omtale savner jeg også en mer overgripende vurdering og sammenligning av funnene i forhold til dagens behandlingspraksis i Norge. I Norge er indikasjonen for aktiv monitorering i dag snevrere enn i PROTECT-studien, og tilbys bare pasienter med lav risikoprofil (PSA $<10 \mu \mathrm{g} / \mathrm{l}$, Gleason-skår $<8$, ikke-palpabel tumor) i prostata og dermed lavere risiko for progrediering. Ifølge årsrapporten fra det nasjonale Prostatacancerregisteret fra 2015 tilhører omtrent $20 \%$ av nydiagnostiserte menn gruppen der aktiv monitorering kan vurderes (4).

Sophie D. Fosså

sopfos@ous-hf.no

Sophie D. Fosså (f. 1941) er professor emerita ved Oslo universitetssykehus, Radiumhospitalet.

Ingen oppgitte interessekonflikter. 